\title{
Minimal effects of reduced teaching hours on undergraduate medical student learning
}

outcomes and course evaluations

Short title: Minimal effects of reduced teaching time

Derek L Choi-Lundberg ${ }^{1}$, Hayder A Al-Aubaidy ${ }^{1,4}$, John R Burgess ${ }^{1}$, Christine A Clifford ${ }^{1}$, William A Cuellar ${ }^{1}$, Judi A Errey ${ }^{1}$, Amanda J Harper ${ }^{3}$, Roslyn C Malley ${ }^{1}$, Renee M Ross ${ }^{1}$, Anne-Marie M Williams ${ }^{1,2}$, and Richard Hays ${ }^{1}$

${ }^{1}$ Division of Medicine and ${ }^{2}$ Division of Paramedicine, School of Medicine, College of Health and Medicine, University of Tasmania, Hobart, Australia; ${ }^{3}$ Student Learning, Retention and Success, Academic Division, University of Tasmania, Hobart, Australia. ${ }^{4}$ School of Life Sciences, La Trobe University, Melbourne, Australia.

\section{Corresponding author:}

Derek L Choi-Lundberg

University of Tasmania

Private Bag 34

Hobart, TAS 7000

+61362262667

derek.choilundberg@utas.edu.au

ORCID iD: (not available for JRB and JAE)

DLCL 0000-0002-3594-8585. HAA 0000-0001-9564-0120. CAC 0000-0001-7613-7888.

WAC 0000-0003-0374-9335. AJH 0000-0002-7980-1438. RCM 0000-0002-3289-5270.

RMR 0000-0001-8361-2712. AMMW 0000-0002-1545-174X. RH 0000-0002-3875-3134.

This is the Accepted Manuscript (AM) version of this manuscript.

The Version of Record of this manuscript has been published and is available in Medical Teacher, (22 August 2019) http://www.tandfonline.com/

https://doi.org/10.1080/0142159X.2019.1652258 


\begin{abstract}
Introduction: Various pressures exist for curricular change, including economic forces, burgeoning knowledge, broadening learning outcomes, and improving quality and outcomes of learning experiences. In an Australian 5-year undergraduate medical course, staff were asked to reduce teaching hours by $20 \%$ to alleviate perceived overcrowded preclinical curriculum, achieve operating efficiencies and liberate time for students' self-directed learning.
\end{abstract}

Methods: A case study design with mixed methods was used to evaluate outcomes.

Results: Teaching hours were reduced by 198 hours (14\%) overall, lectures by 153 hours (19\%) and other learning activities by 45 hours (7\%). Summative assessment scores did not change significantly after the reductions: $0.4 \%$ increase, $1.5 \%$ decrease and $1.7 \%$ increase in Years 1, 2 and 3, respectively. The percentage of students successfully completing their academic year did not change significantly: $94.4 \%$ before and $93.3 \%$ after the reductions. Student evaluations from eVALUate surveys changed little, except workload was perceived to be more reasonable.

Conclusions: Teaching hours, particularly lectures, can be moderately reduced with little impact on student learning outcomes or satisfaction with an undergraduate medical course.

\title{
Key words:
}

undergraduate medical students, curriculum development, student evaluation, learning environment, engagement in learning, eVALUate questionnaire 


\section{Introduction}

Many medical schools are striving to improve their programs, with competing pressures from several directions. First, students and universities are seeking greater flexibility in learning to allow a better balance of study, extra-curricular, work, family, social and leisure activities (Brint and Cantwell 2010; Hall 2010; Burston 2017; Ask and Abidin 2018) and to provide time for self-care to look after health and well-being (Warnecke et al. 2011; Slavin et al. 2014; Ask and Abidin 2018). Second, student preferences for learning resources and activities vary as online resource availability increases (Wanner and Palmer 2015; ChoiLundberg et al. 2016; Rickes 2016; Henderson et al. 2017). Third, universities are seeking operating efficiencies by increasing student numbers (raising income) and decreasing staff (lowering costs), while enhancing reputations through stronger research outcomes (Parker 2013). Fourth, regulators and employers are seeking changes based on contemporary views on professional roles, employability and work readiness (Frenk et al. 2010; Australian Medical Council 2012; Murdoch-Eaton and Whittle 2012; Jackson 2016; Merga 2016; Rowe and Zegwaard 2017). Fifth, recent and proposed undergraduate medical curricular changes include shortening the preclinical curriculum; integrating basic, clinical and social sciences with clinical experience; and placing a greater focus on team-based patient-centred quality health care, population health, professional identity formation, and collaborative and selfdirected learning and inquiry (Wilkerson et al. 2009; Irby et al. 2010; Fischel et al. 2018). Sixth, the exponential growth of scientific knowledge (Bornmann and Mutz 2015) means it is impossible to teach everything, so students must develop lifelong learning skills including finding and critically evaluating information (Murdoch-Eaton and Whittle 2012).

Meanwhile, teaching staff often respond to competing curricular demands in a reflexive way. Adding lectures and workshops is easier than removing them to make space for new content, whether knowledge, skills or attitudes (Densen 2011; Lomis et al. 2017; 
Doukas and Volpe 2018; Gonzalo et al. 2018). This may result in overcrowded programs with less time for self-directed learning for students and increased teaching workloads for staff. In contrast, reducing face-to-face teaching hours can liberate staff time for research and other academic activities (Boyer 1990) while satisfying student demands for less classroom time and more opportunity for self-directed learning. Hence, managing both academic and student workloads is an essential part of curriculum revision.

It may seem reasonable to assume that increased instructional time, a key input in education (Duncheon and Tierney 2013), would increase learning. This appears true in primary and secondary schooling, where increasing schooling time and time-on-task improves student achievement (Carroll 1989). Similarly, across several different university courses (e.g., teacher education, biology and engineering), the number of scheduled lectures and practicals is positively associated with students passing more units of study, and attendance at lectures and practicals has positive correlations with grade point average and class grades (Credé et al. 2010; Torenbeek et al. 2013). However, there may be a trade-off between the quantity of formal teaching and the time students devote to self-directed learning, viewing time as a scarce, fixed resource (Duncheon and Tierney 2013). Reports from medical, engineering and other demanding programs show that although increasing instruction time leads initially to more time spent on self-study, excessive instruction time (sometimes defined as more than 20 hours per week) reduces time spent on self-study (studies by Vos and colleagues, discussed in Gijselaers and Schmidt 1995; Kember et al. 1996; Torenbeek et al. 2013). Comparing all eight medical schools in the Netherlands, programs with more lectures per week were associated with less self-study time, lower graduation rates and more years taken to graduate (Schmidt et al. 2010). There are also concerns that high teaching hours cause students to perceive a heavy workload, which may discourage deep learning and encourage surface learning approaches (Kember 2004). Hence, 
calls have echoed through recent decades to reduce delivered content to allow more time for learners to reflect and integrate new knowledge (Newble and Entwistle 1986; Kember and Leung 1998; Baeten et al. 2010). For example, reducing teaching hours by $10 \%$ through eliminating unnecessary detail, but simultaneously introducing elective programs, learning communities and mindfulness experiences, lowered stress, anxiety and depression in preclinical medical students while maintaining academic learning outcomes at a national licensure examination (Slavin et al. 2014).

The present case study explored the impact of reduced teaching hours on students' learning, progression, motivation and perceptions of the learning environment in an Australian 5-year undergraduate medical (MBBS) program preparing for an accreditation review by the Australian Medical Council. Based on document review and student feedback, the curriculum was deemed too reliant on teacher-delivered content, particularly in Year 1 (Y1) and Year 2 (Y2) which had an average of 13 hours per week of lectures and 10 hours per week of other learning activities, such as laboratory practicals, tutorials, and workshops. In response, a decision was made to reduce teaching hours by about $20 \%$ across the preclinical curriculum while maintaining assessment task load. Research questions included the following:

- What reductions in teaching hours were achieved compared with the target, and how did reductions vary across areas of the preclinical curriculum?

- Did learning outcomes, as measured by overall summative assessment scores and progression rates, differ before and after implementation of reductions?

- How did student motivation and opinions of the course compare before and after the reductions, as measured by the eVALUate course experience and satisfaction questionnaire (Oliver et al. 2008)? 


\section{Methods}

This project was approved by the University of Tasmania (UTAS) Social Sciences Human Research Ethics Committee (approval number H0016408).

\section{Research methodology}

The present case study research utilised a single case, from the authors' local context, and was evaluative in its approach (Cheek et al. 2018). Changes in one naturalistic educational setting aimed at improving the learning environment (Genn 2001b) were retrospectively examined over time ('diachronic'), comparing the last two years before teaching-hour reductions (2013 and 2014) with the first two years of implementation of reductions (2015 and 2016). The study utilised mixed methods, incorporating quantitative and qualitative analyses (Schifferdecker and Reed 2009) as described below. The data included students' overall summative assessment scores, progression rates, and student course evaluations using the eVALUate instrument (Oliver et al. 2008). Additionally, a variety of documents were analysed, including unit outlines (course descriptions), timetables, documents prepared for accreditation and proposals detailing curriculum changes and their rationale.

\section{Teaching and learning context}

The 5-year undergraduate MBBS program at UTAS has approximately 120 students per cohort, most of whom enter directly after completing year 12, although some enter after completing part or all of another undergraduate university course. Most authors of this paper taught in the MBBS course over the time reported in this case study.

The MBBS curriculum both before and after teaching-hour reductions used the four domains from the 'Standards for Assessment and Accreditation of Primary Medical Programs by the Australian Medical Council 2012' (Australian Medical Council 2012) as organising principles. Further details of the curriculum are provided in Appendix 1. 


\section{Teaching hours before and after reductions}

Final versions of timetables were obtained for each semester of Y1 to Y3 in 2014 (last year before reductions) and 2015 (first year of implementation of reductions). The number of hours of teaching sessions were tallied and reported by total hours, lecture hours, and other learning activity hours (e.g., tutorial, laboratory practical, workshop, information sessions, etc.), as well as by subject areas of the curriculum plus case-based learning sessions, which are integrated across subjects.

\section{Characterisation of reductions made to curriculum}

Documents prepared for the School of Medicine Learning and Teaching Committee and associated planning documents, which detailed the 2014 curriculum and proposed changes for 2015 with rationale for changes, were analysed. Unit outlines (descriptions of the year of study provided to students and staff) for Y1 to Y3 of the MBBS course from 2013 to 2016 were analysed to compare descriptions of the units and intended learning outcomes before and after teaching-hour reductions.

\section{Students' learning outcomes as measured on summative assessments}

Students' assessment results in Y1 to Y3 of the MBBS course in 2013 to 2016 were obtained from spreadsheets used by unit coordinators to record and track student progress for reporting, feedback and quality assurance purposes. Descriptions of assessment tasks were obtained from unit outlines and remained the same before and after teaching-hour reductions; a summary is provided in Appendix 2.

\section{Student feedback on units of the MBBS course}

Student feedback was obtained from eVALUate unit reports provided to unit coordinators by the Survey Team from Curriculum \& Quality, Academic Division at UTAS. The reports provided response rates, summary data on selected-response items and full text of anonymous 
open-response comments. Reports were released to academic staff after finalisation and release of students' grades. The Survey Team also provided anonymous individual responses to each selected-response item for this research project.

The eVALUate instrument (Oliver et al. 2008) seeks students' opinions on the extent to which various aspects of the learning environment contribute to achieving learning outcomes, their engagement in the unit of study and overall satisfaction through eleven selected-response items (Table 4) with four-point Likert scales: 1=strongly disagree (SD), $2=$ disagree (D), 3=agree (A) and 4=strongly agree (SA); 'Unable to judge' (UJ) is also available as a response option (Oliver et al. 2008). The eVALUate instrument also has two open-response questions: 'What are the most helpful aspects of this unit?' and 'How do you think this unit might be improved?' (Oliver et al. 2008). Students were invited to complete the survey at the end of each semester during a 4-week window including the examination period.

Data from eVALUate in each of the first six semesters of the MBBS course were analysed from 2012 semester 2 (S2) through 2016 S2. Comparisons were made between 2012 S2, 2013 S1 and S2, and 2014 S1 (before teaching-hour reductions) and 2015 and 2016 S1 and S2 (after teaching-hour reductions). Data from 2014 S2 were excluded due to very low response rates.

\section{Statistical analyses}

Quantitative data were analysed in Excel (Microsoft Corporation, Redmond, WA) and SPSS statistical package, version 22 (IBM Corporation, Armonk, NY). Parametric data are presented as mean (standard deviation). Assessment results and Likert-scale student opinions from unit evaluations before and after teaching-hour reductions were compared by independent-sample t-tests for normally distributed data or Mann-Whitney U tests for non- 
normally distributed data, with normality assessed by the Shapiro-Wilk test and visual inspection of histograms. 'Unable to judge' or missing responses on the eVALUate survey were excluded from analyses on a case-by-case basis. Reliability (internal consistency) of the eVALUate survey was determined by computing Cronbach's alpha. The conservative Bonferroni correction was used to adjust the $P$-value considered statistically significant by dividing by the number of comparisons made in each of Y1, Y2 and Y3, $P<0.017(0.05 / 3)$; in each of the 6 units (year 1 semester 1 (Y1S1), Y1S2, Y2S1, Y2S2, Y3S1 and Y3S2), $P<0.008(0.05 / 6)$; or on unit eVALUate with overall scores and eleven individual items, $P<0.004(0.05 / 12)$. The chi-square $\left(\chi^{2}\right)$ test of contingencies, or 2 -sided Fisher's exact test if one or more expected frequency counts were less than five, were used to compare the number of students not completing or completing but failing the academic year, and the number of open-response comments in a given theme before vs. after teaching-hour reductions.

\section{Document analysis}

Documents relevant to research questions were obtained from the authors' records and UTAS School of Medicine digital archives. Text documents were examined using the method of document analysis, in which the intended audience, context and purpose were considered while extracting, interpreting and synthesising information relevant to addressing research questions (Bowen 2009).

\section{Qualitative analysis of student feedback from open-response items on eVALUate}

Student comments were manually coded and themes identified using the method of thematic analysis (Braun and Clarke 2006). Additionally, the data underwent content analysis and concept mapping using Leximancer v4 (Leximancer Pty Ltd, Brisbane, QLD, Australia) computer-aided qualitative data analysis software (CAQDAS) that uses text-mining processes to identify key concepts and their relationships (Thomas 2014). 


\section{Results}

\section{Reductions in teaching hours}

A reduction in teaching hours of 14\% (198 hours) was achieved (Figure 1 and Table 1) across Y1 (89 hours), Y2 (63 hours) and Y3 (46 hours). Lecture hours were reduced by 19\% (153 hours), with greater reductions in Y1 (81 hours) and Y2 (60 hours) compared with Y3 (13 hours). In contrast, other learning activities were reduced by $7 \%$ (45 hours), with small reductions in Y1 (8 hours) and Y2 (4 hours), but comparatively large reductions in Y3 (33 hours). Numbers presented in the text may differ by one hour from data presented in Table 1 due to rounding. Table 2 summarises teaching-hour reductions in each major area of the curriculum. Appendix 3 provides additional descriptive details.

[Figure 1, Table 1\&2 near here]

\section{Summative assessment scores and progression rates}

The percentage of students not completing the academic year (withdrew or did not sit final examinations), as well as the percentage of students that completed the year but failed, did not differ before and after teaching-hour reductions. Of those students who completed the year (whether pass or fail), the overall summative assessment scores did not differ before and after teaching-hour reductions (Table 3). Prior to conducting these analyses, it was confirmed that in each of Y1 to Y3, scores did not significantly differ between 2013 and 2014 (before the reductions), nor between 2015 and 2016 (after the reductions) at $P=0.008$ (Bonferroni correction for six comparisons); hence, 2013 and 2014 scores were pooled, and 2015 and 2016 scores were pooled.

[Table 3 near here] 


\section{Student opinions: eVALUate questionnaire Likert-scale questions}

Across four years and six units, a total of $N=1093$ responses were received to the eVALUate course experience and satisfaction questionnaire. An average (standard deviation) of $40 \%$ (11\%) of enrolled students responded to eVALUate in each unit, which compared favourably with response rates of $36 \%(5 \%)$ across the university during the same semesters.

The eleven Likert-scale items of eVALUate had good reliability, with Cronbach's alpha of 0.86 ( $N=909$ usable responses; $N=184$ responses were excluded due to at least one 'unable to judge' or missing response). Each item was not overly similar to other items, with weak to strong inter-item correlations ranging from $r=0.142$ to 0.683 , mean 0.375 . Each item had moderate to strong correlation with the remainder of the questionnaire (sum of the other 10 items), ranging from $r=0.408$ to 0.711 , mean 0.566 .

The average across all eleven eVALUate items and nine of the eleven individual items did not differ significantly before vs after teaching-hour reductions (Table 4). Ratings on item 4 , relating to assessment tasks, increased by 0.15 and percentage agreement (SA or A) increased by $5 \%$. However, none of the six individual units had significant differences on this item at $P=0.008$. Ratings on item 6, relating to workload, increased by 0.24 and percentage agreement increased by $12 \%$. Three of the six units had significant increases in ratings on this item: Y1S2 (0.32 increase), Y2S1 (0.34 increase), and Y2S2 (0.33 increase), all $P \leq 0.001$. The other three units had non-significant increases: Y1S1 (0.15 increase), Y3S1 (0.19 increase), and Y3S2 (0.03 increase).

[Table 4 near here] 


\section{Students' evaluation of the course: Qualitative analysis of eVALUate questionnaire open- response items}

Students' comments on the two open-response items of eVALUate were analysed. There were no changes in the percentages of responses to the 'most helpful' and 'how to improve' questions before vs after the reductions $\left(\chi^{2}=0.06, P=0.81\right)$ : In the two years prior to teachinghour reductions across six units, there were a total of 702 comments, $342(48.7 \%)$ and 360 $(51.3 \%)$ to the two questions, respectively. In the two years after implementation of the reductions, there were a total of 585 comments, $281(48.0 \%)$ and $304(52.0 \%)$ to the two questions, respectively.

Content analysis and concept mapping using Leximancer v4 revealed similar dominant and well-connected themes and concepts before and after teaching-hour reductions. The most helpful aspects, as well as suggestions for improvement, centred on lectures, tutorials, practicals, content, learning and lecturers. Another central and well-connected theme was 'time'.

The themes and concepts identified with Leximancer v4 aligned with independently performed manual coding of comments using thematic analysis by two authors. There was a non-significant reduction in the number of comments indicating too much content or excessive teaching hours, from $40(5.7 \%)$ comments before reductions to $23(3.9 \%)$ comments afterwards $\left(\chi^{2}=2.14, P=0.14\right)$. For example, 'There are a lot of contact hours which makes it very difficult to find time to review the material given to us' (Y2S2 before), 'the work load is just ridiculous ... it just becomes so tiring and demotivating having so much to learn and not being able to remember it all' (Y2S1 before) and 'the volume of work / learning required is quite significant and, at times, overwhelming' (Y1S1 after). Some students, after the reductions, appreciated having less teaching time: 'Less contact hours ... meant we had more time to consolidate knowledge and write up notes' (Y1S2 after), while 
others felt more teaching time would assist learning: 'More contact hours, while increasing the amount of material, may help give better connections and hence make material cement better' (Y1S2 after).

There was a significant increase in comments requesting more tutorials and/or practical laboratories, from $47(6.7 \%)$ before to $72(12.3 \%)$ after the reductions $\left(\chi^{2}=11.98\right.$, $P=0.001)$. For example, 'I would happily attend tutorials over having private study time as they provide more guided teaching/learning, which I think is necessary to complement the vast quantity delivered each lecture' (Y1S1 after). Only 4 comments $(<1 \%)$ requested fewer tutorials and/or practical laboratories both before and after the reductions. There was a nonsignificant increase in the number of comments requesting more lectures, from $13(1.9 \%)$ to $21(3.6 \%)$ comments before and after the reductions, respectively $\left(\chi^{2}=3.75, P=0.053\right)$, e.g., ' $I$ would have liked more lectures ... to cover content completely' (Y1S2 after). A similar number of comments requested fewer lectures, 27 (3.8\%) before and $30(5.1 \%)$ after the reductions $\left(\chi^{2}=1.24, P=0.27\right)$, e.g., 'There are WAY too many lectures scheduled this semester' (Y3S2 before).

Eight comments specifically praised the reduction in teaching hours, mostly for enabling more time for self-directed study: 'It has been great since the contact hours have been reduced, learn much more when doing independent study' (Y2S1 after). In contrast, six comments criticised the reduction, for example, 'At times I felt as though the same (or very similar) amount of content was attempted to be delivered in a significantly reduced amount of time' (Y1S2 after). 


\section{Discussion}

This case study demonstrated that it is possible to reduce instructional time by approximately 200 hours (14\%) through eliminating non-core and repetitious content in the preclinical curriculum of an undergraduate medical course without significantly impacting on curriculum coverage, progression rates, assessment outcomes, and student opinions of many aspects of the educational environment and their engagement. Furthermore, teaching-hour reductions, particularly the $19 \%$ reduction in lecture hours, were generally seen as less burdensome by students, with more students agreeing that the workload was appropriate to achieving learning outcomes. These findings align with a report from Saint Louis University School of Medicine, in which unnecessary detail was eliminated from the curriculum, enabling an approximately $10 \%$ contact-hour reduction, along with other initiatives to improve the learning environment, resulting in improved student wellness and maintenance of academic learning outcomes assessed through the pre-clinical step of the United States Medical Licensing Examination (Slavin et al. 2014).

These results should be reassuring for all participants. For staff, teaching loads can be reduced without reducing student learning or perceived quality of learning experiences. For students, additional lectures add little if they consume time that may otherwise be invested in self-directed learning or studying with peers. Teaching-hour reductions eventually allowed for increased time for staff to invest in research, administration, service and community engagement activities after the additional workload associated with designing and implementing the reductions was completed. However, there was significantly increased workload for academic staff in the year leading up to the reductions and the year of the reductions. Tasks included meeting to debate and decide on curriculum changes, documenting decisions, and implementing the changes including timetabling, assessment blueprinting, and rewriting lectures and student notes for laboratory practicals and tutorials. 
The success of this project may lie in the comprehensive and whole-team approach to changing the curriculum, encouraging participation throughout the change process by all teaching staff (Genn 2001a). Engaging academics or teachers is emphasised in educational change literature (Hopkins et al. 2015). Although initially suggested by program leadership in response to reviews and student feedback, when the rationales for change (e.g., accreditation drivers and increased time for students and staff) were explained and discussed, the vast majority of staff embraced the task and worked collaboratively, rigorously and systematically towards the goal (Bland et al. 2000). Staff responsible for each subject area were empowered to decide what to remove. Because teaching hours were to be decreased equally in all areas of the curriculum (although there was variability in implementation, Table 2), staff did not perceive diminished value or emphasis of their subject in the curriculum, which otherwise may have decreased engagement in change (Venance et al. 2014).

Student comments indicated that some were pleased with the changes while others were dissatisfied. More communication of the rationale for change may have promoted greater acceptance, as would student involvement in committees to provide input into curriculum development and ongoing feedback (Yengo-Kahn et al. 2017). A new governance structure for the MBBS course, with student representation on all committees, was established after implementation of this curriculum change.

\section{Limitations}

This case study occurred in a naturalistic educational setting and the quasi-experimental, time series design is less powerful than other experimental designs. While quantitative comparisons were strengthened by including two years of data both before and after the intervention from three years of the course, transferability of the findings to other higher education courses, including medical, remains to be determined. In a complex program such 
as medicine, there are potentially many contributing factors that shape students' experiences, learning outcomes and progression rates, so it is possible to report only high-level outcomes. The eVALUate survey was designed for all programs at universities (Oliver et al. 2008), and while its items are relevant to this project, it did not address other important aspects of the educational environment, such as classroom ethos and student support systems, as measured in instruments such as the Dundee Ready Education Environment Measure (DREEM) (Roff et al. 1997; Soemantri et al. 2010; Chan et al. 2018). Finally, this study did not attempt formally to measure student time spent in self-directed learning, effects on students' stress and mental health, or opinions of staff about the teaching-hour reductions and processes.

\section{Conclusion}

Medical programs are reputed to be academically intense, with more crowded curricula and less free time than in many other university programs. This project demonstrated that it is possible to reduce teaching hours by $14 \%$ (including lectures by $19 \%$ ) without negative impacts on student learning. This offers the advantages of freeing staff time for other academic activities and providing more time for student self-directed learning. Achieving these positive outcomes may be enhanced through a whole-team approach to curriculum change.

\section{Practice points}

- Lecture hours can be reduced considerably and other learning activities reduced moderately with no impact on student learning outcomes and progression rates.

- Student evaluations of the course were minimally impacted by teaching-hour reductions, except for an increase in the percentage agreeing that the workload was reasonable. 


\section{Acknowledgements}

The authors thank Professor Ben Canny for helpful comments on the manuscript, academic colleagues who contributed to curriculum design, teaching, and assessing in the MBBS course; administrative team members for assistance with timetable and assessment data entry; and the Survey Team from Curriculum \& Quality, Academic Division of UTAS, for running the eVALUate surveys and providing summary data as well as anonymous individual responses for this project.

\section{Declarations of interest}

No financial support was received for this project. Richard Hays is a member of the editorial board of Medical Teacher. Preliminary data from this study were presented as an oral presentation at the APMEC conference: Hays R, Al-Aubaidy H, Cuellar W, Dwyer R, Williams AMM, and Choi-Lundberg DL. 2018. Effects on student results and course evaluations of reduction in teaching hours in an undergraduate medical course. 15th Asia Pacific Medical Education Conference (APMEC). 10-14 Jan, Singapore.

\section{Notes on contributors}

Hayder Al-Aubaidy, MBChB, $\mathrm{PhD}$, senior lecturer, teaches human gross anatomy and neuroanatomy to undergraduate allied health students at La Trobe University. His research interests include medical education as well as measures to improve the outcomes of diabetes and cardiovascular disease.

John Burgess, MBBS, MD, PhD, FRACP, Professor of Endocrinology, was formerly the Director of MBBS Years 1-3 during period when the teaching-hours reduction was planned and implemented.

Derek L. Choi-Lundberg, $\mathrm{PhD}$, senior lecturer, teaches gross anatomy, neuroanatomy, and embryology to Y1 to Y3 medical students, chairs the Y1 MBBS management committee 
and coordinates Y1S1 or Y1S2 of the MBBS course. His research interests include medical education, technology-enhanced learning, assessment, and student learning approaches in anatomy.

Christine Clifford, PhD, senior lecturer and clinical psychologist, teaches communication skills and mental health to Y1 to Y4 medical students. She is associate unit coordinator of Y3 and the Clinical Practice Domain representative on the Y1 MBBS management committee. Her research focusses on medical education, particularly mental health literacy.

William A Cuellar, BApp Sc (Physiotherapy), lecturer, teaches anatomy to Y1-Y3 and musculoskeletal clinical skills to Y1 medical students. He coordinates Y1S1 or Y1S2 of the MBBS course. His research interests include medical education, applied anatomy, epidemiology and age-related changes in muscles of the trunk of older adults.

Judi Errey, BSc, MBBS, senior lecturer, is the clinical coordinator for Y1 and Y2 of the MBBS and teaches clinical aspects of the cardiovascular system. Her research interests include medical education, technology-enhanced learning, and assessment and acquisition of clinical skills in pre-clinical students.

Amanda J. Harper, PhD, coordinates the Bachelor of Philosophy, a companion degree for gifted and high achieving students at the University of Tasmania, Australia. Her research includes the place of gifted education pedagogy in undergraduate healthcare delivery, particularly focusing on the development of empathy, and Dąbrowski's Theory of Positive Disintegration.

Richard Hays is Professor of Medical Education at the University of Tasmania. He was the Dean of Medicine at the time of the project reported in this paper, as well as a teacher in the primary care, rural health and professionalism components of the medical program. 
Roslyn C Malley, MBBS, PhD, Lecturer and practicing general pathologist, teaches pathology in Years 1-3 of the MBBS course. She has contributed to research projects in medical education, immunology, microbiology, and anatomical and chemical pathology.

Renee M Ross, $\mathrm{PhD}$, Senior Lecturer, teaches biochemistry and physiology in Years 1-3 of the MBBS and Bachelor of Medical Research (BMedRes), chairs the Year 2 MBBS management committee and is unit coordinator of Y2S1 of the MBBS course. Her research focuses on muscle metabolism, vascular function and exercise in type 2 diabetes.

Anne-Marie Williams, $\mathrm{PhD}$, Associate Professor, teaches gross anatomy in the second year of the MBBS. She is head of the Division of Paramedicine and has previously held the position of Associate Head Learning and Teaching in the School of Medicine. Her research interests include medical/paramedicine education, technology-enhanced learning, assessment, and student learning approaches in anatomy. 


\section{References}

Ask K, Abidin C. 2018. My life is a mess: Self-deprecating relatability and collective identities in the memification of student issues. Inf Commun Soc. 21(6):834-850.

Australian Medical Council. 2012. Standards for Assessment and Accreditation of Primary Medical Programs by the Australian Medical Council 2012. Kingston, ACT: Australian Medical Council Limited. p. 21.

Baeten M, Kyndt E, Struyven K, Dochy F. 2010. Using student-centred learning environments to stimulate deep approaches to learning: Factors encouraging or discouraging their effectiveness. Educ Res Rev. 5(3):243-260.

Biggs J, Tang C. 2007. Teaching for quality learning at university. 4th ed. Maidenhead, Berkshire, UK: Open University Press.

Bland CJ, Starnaman S, Wersal L, Moorhead-Rosenberg L, Zonia S, Henry R. 2000. Curricular change in medical schools: How to succeed. Acad Med. 75(6):575-594.

Bornmann L, Mutz R. 2015. Growth rates of modern science: A bibliometric analysis based on the number of publications and cited references. J Assoc Inf Sci Technol. 66(11):2215-2222.

Bowen GA. 2009. Document analysis as a qualitative research method. Qual Res J. 9(2):2740.

Boyer EL. 1990. Scholarship Reconsidered: Priorities of the Professoriate. San Francisco: Jossey-Bass.

Braun V, Clarke V. 2006. Using thematic analysis in psychology. Qual Res Psych. 3(2):77101. 
Brint S, Cantwell A. 2010. Undergraduate time use and academic outcomes: Results from the University of California undergraduate experience survey 2006. Teach Coll Rec. 112(9):2441-2470.

Burston MA. 2017. I work and don't have time for that theory stuff: Time poverty and higher education. J Further High Educ. 41(4):516-529.

Carroll JB. 1989. The Carroll model: A 25-year retrospective and prospective view. Educ Res. 18(1):26-31.

Chan CYW, Sum MY, Tan GMY, Tor P-C, Sim K. 2018. Adoption and correlates of the Dundee Ready Educational Environment Measure (DREEM) in the evaluation of undergraduate learning environments - a systematic review. Med Teach. 40(12):12401247.

Cheek C, Hays R, Smith J, Allen P. 2018. Improving case study research in medical education: a systematised review. Med Educ. 52(5):480-487.

Choi-Lundberg DL, Low TF, Patman P, Turner P, Sinha SN. 2016. Medical student preferences for self-directed study resources in gross anatomy. Anat Sci Educ. $9(2): 150-160$.

Credé M, Roch SG, Kieszczynka UM. 2010. Class attendance in college: A meta-analytic review of the relationship of class attendance with grades and student characteristics. Rev Educ Res. 80(2):272-295.

Densen P. 2011. Challenges and opportunities facing medical education. Trans Am Clin Climatol Assoc. 122:48.

Doukas DJ, Volpe RL. 2018. Why pull the arrow when you cannot see the target? Framing professionalism goals in medical education. Acad Med. 93(11):1610-1612. 
Duncheon JC, Tierney WG. 2013. Changing conceptions of time: Implications for educational research and practice. Rev Educ Res. 83(2):236-272.

Fischel JE, Olvet DM, Iuli RJ, Lu W-H, Chandran L. 2018. Curriculum reform and evolution: Innovative content and processes at one US medical school. Med Teach.

Frenk J, Chen L, Bhutta ZA, Cohen J, Crisp N, Evans T, Fineberg H, Garcia P, Ke Y, Kelley P et al. 2010. Health professionals for a new century: Transforming education to strengthen health systems in an interdependent world. Lancet. 376(9756):1923-1958.

Genn J. 2001a. AMEE Medical Education Guide No. 23 (Part 1): Curriculum, environment, climate, quality and change in medical education-a unifying perspective. Med Teach. 23(4):337-344.

Genn J. 2001b. AMEE Medical Education Guide No. 23 (Part 2): Curriculum, environment, climate, quality and change in medical education-a unifying perspective. Med Teach. 23(5):445-454.

Gijselaers WH, Schmidt HG. 1995. Effects of quantity of instruction on time spent on learning and achievement. Educ Res Eval. 1(2):183-201.

Gonzalo JD, Caverzagie KJ, Hawkins RE, Lawson L, Wolpaw DR, Chang A. 2018. Concerns and responses for integrating health systems science into medical education. Acad Med. 93(6):843-849.

Hall R. 2010. The work-study relationship: Experiences of full-time university students undertaking part-time employment. J Educ Work. 23(5):439-449.

Henderson M, Selwyn N, Aston R. 2017. What works and why? Student perceptions of 'useful' digital technology in university teaching and learning. Stud High Educ. 42(8):1567-1579. 
Hopkins R, Pratt D, Bowen JL, Regehr G. 2015. Integrating basic science without integrating basic scientists: Reconsidering the place of individual teachers in curriculum reform. Acad Med. 90(2):149-153.

Irby DM, Cooke M, O'Brien BC. 2010. Calls for reform of medical education by the Carnegie Foundation for the Advancement of Teaching: 1910 and 2010. Acad Med. 85(2):220-227.

Jackson D. 2016. Skill mastery and the formation of graduate identity in bachelor graduates: Evidence from Australia. Stud High Educ. 41(7):1313-1332.

Kember D. 2004. Interpreting student workload and the factors which shape students' perceptions of their workload. Stud High Educ. 29(2):165-184.

Kember D, Leung DYP. 1998. Influences upon students' perceptions of workload. Educ Psychol. 18(3):293-307.

Kember D, Ng S, Tse H, Wong ET, Pomfret M. 1996. An examination of the interrelationships between workload, study time, learning approaches and academic outcomes. Stud High Educ. 21(3):347-358.

Lomis K, Amiel JM, Ryan MS, Esposito K, Green M, Stagnaro-Green A, Bull J, Mejicano GC. 2017. Implementing an entrustable professional activities framework in undergraduate medical education: early lessons from the AAMC core entrustable professional activities for entering residency pilot. Acad Med. 92(6):765-770.

Merga MK. 2016. Gaps in work readiness of graduate health professionals and impact on early practice: Possibilities for future interprofessional learning. Focus Health Prof Educ. 17(3):14-29. 
Murdoch-Eaton D, Whittle S. 2012. Generic skills in medical education: Developing the tools for successful lifelong learning. Med Educ. 46(1):120-128.

Newble D, Entwistle N. 1986. Learning styles and approaches: Implications for medical education. Med Educ. 20(3):162-175.

Oliver B, Tucker B, Gupta R, Yeo S. 2008. e VALUate: an evaluation instrument for measuring students' perceptions of their engagement and learning outcomes. Assess Eval High Educ. 33(6):619-630.

Parker LD. 2013. Contemporary university strategising: the financial imperative. Fin Account Manag. 29(1):1-25.

Rickes PC. 2016. Generations in flux: How Gen Z will continue to transform higher education space. Plan High Educ. 44(4):21-45.

Roff S, McAleer S, Harden RM, Al-Qahtani M, Ahmed AU, Deza H, Groenen G, Primparyon P. 1997. Development and validation of the Dundee ready education environment measure (DREEM). Med Teach. 19(4):295-299.

Rowe AD, Zegwaard KE. 2017. Developing graduate employability skills and attributes: Curriculum enhancement through work-integrated learning. Asia Pac J Coop Educ. 18(2):87-99.

Schifferdecker KE, Reed VA. 2009. Using mixed methods research in medical education: Basic guidelines for researchers. Med Educ. 43(7):637-644.

Schmidt HG, Cohen-Schotanus J, van der Molen HT, Splinter TA, Bulte J, Holdrinet R, van Rossum HJ. 2010. Learning more by being taught less: A "time-for-self-study" theory explaining curricular effects on graduation rate and study duration. High Educ. 60(3):287-300. 
Slavin SJ, Schindler DL, Chibnall JT. 2014. Medical student mental health 3.0: Improving student wellness through curricular changes. Acad Med. 89(4):573-577.

Soemantri D, Herrera C, Riquelme A. 2010. Measuring the educational environment in health professions studies: a systematic review. Med Teach. 32(12):947-952.

Thomas DA. 2014. Searching for significance in unstructured data: Text mining with leximancer. Eur Educ Res J. 13(2):235-256.

Torenbeek M, Jansen E, Suhre C. 2013. Predicting undergraduates' academic achievement: The role of the curriculum, time investment and self-regulated learning. Stud High Educ. 38(9):1393-1406.

Venance SL, LaDonna KA, Watling CJ. 2014. Exploring frontline faculty perspectives after a curriculum change. Med Educ. 48(10):998-1007.

Wanner T, Palmer E. 2015. Personalising learning: Exploring student and teacher perceptions about flexible learning and assessment in a flipped university course. Comput Educ. 88:354-369.

Warnecke E, Quinn S, Ogden K, Towle N, Nelson MR. 2011. A randomised controlled trial of the effects of mindfulness practice on medical student stress levels. Med Educ. 45(4):381-388.

Wilkerson L, Stevens CM, Krasne S. 2009. No content without context: Integrating basic, clinical, and social sciences in a pre-clerkship curriculum. Med Teach. 31(9):812-821.

Yengo-Kahn AM, Baker CE, Lomis K. 2017. Medical students' perspectives on implementing curriculum change at one institution. Acad Med. 92(4):455-461. 


\section{Appendices (Supplementary online material)}

\section{Appendix 1. Description of Years 1-3 of the MBBS curriculum}

Domain 1, 'Science and Scholarship: the medical graduate as scientist and scholar' (Australian Medical Council 2012), in the first three years of the MBBS course followed a scientific discipline-based curriculum integrated by organ systems, except for Year 1 Semester 1 (Y1S1), which focused on foundations of basic sciences (biochemistry, cell biology, histology, gross anatomy and physiology) and pathology (including immunology and microbiology), and Y3S2, which focused on multisystem diseases including metabolic disorders, immune disorders and malignancy.

Domain 2, 'Clinical Practice: the medical graduate as practitioner' (Australian Medical Council 2012), included development of communication skills and was integrated with Domain 1 through teaching of clinical history and examination skills relating to each organ system in Y1S2 to Y2S2. Pharmacology, radiology, and clinical sciences were also included in Domain 2.

Domain 3, 'Health and Society: the medical graduate as a health advocate' (Australian Medical Council 2012), explored the meanings and determinants of health, the range of patient populations, the roles of medical practitioners in the Australian health care system and the wider Australian community, and global perspectives.

Domain 4, 'Professionalism and Leadership: the medical graduate as a professional and leader' (Australian Medical Council 2012), developed life-long learning skills and professional identity and examined biopsychosocial, ethical and legal frameworks of the doctor-patient relationship.

Weekly case-based learning (CBL) tutorials provided clinical cases to which learning activities of all Domains related. In Y3, three days per week students were on ward-based 
rotations of eight weeks duration each, in Medicine, Surgery, Primary Care and Clinical Specialities (including Paediatrics, Psychiatry, and Obstetrics and Gynaecology). The two days per week preclinical program in Y3 was included in the present case study, but not the ward-based curriculum.

\section{Appendix 2. Description of assessment tasks in Years 1-3 of the MBBS}

In Y1 and Y2, assessment tasks were similar, and included in each semester the following: one mid-semester and two end-of-semester written examinations, a laboratory-based practical examination, and two or three written essays or assignments. Additionally, in Y2, there was a four-station objective structured clinical examination (OSCE) and a small-group long case presentation. In Y3S1, there was one mid-semester and one end-of-semester written examination, and a laboratory-based practical examination. In Y3S2, there were two end-ofsemester written examinations, one for the academic component and one for the clinical rotations. Written examinations generally included a mix of multiple-choice questions (MCQ, single correct response from five options), extended matching questions (EMQ), short answer questions (SAQ) and short essay questions (SEQ). Practical examinations included mostly SAQ with some SEQ. Examination questions were aligned to teaching and learning activities and intended learning outcomes (Biggs and Tang 2007), but specific questions on examinations generally varied from year to year.

There were also several summative assessment tasks that did not contribute marks to the overall grade and percentage score but had to be satisfactorily completed to pass the year. These results were used in addition to the assessments described above to determine if students passed the academic year (Table 3). These tasks varied across years and semesters of the course, but did not change across the case study period, and included personal and professional development portfolio entries, online discussion posts, small-group case-based presentations, visits to community health organisations, and OSCEs in Y1 and Y3. 


\section{Appendix 3. Description of teaching-hour reductions by subject area}

Staff were asked to reduce total teaching hours by $20 \%$. The overall curriculum philosophy and organisation and intended learning outcomes were not changed. Teaching staff in all subject areas were asked to identify content that was repetitive within or across semesters or years, or addressed non-core content that could be eliminated while preserving overall curriculum integrity. A particular focus was reducing the number of lectures; however, reducing the duration and number of laboratory practical sessions were also goals. Working parties were established for each Domain and scientific subject area, and these groups reviewed their preclinical curriculum and proposed reductions and reorganisation of content across years and/or semesters. Unit coordinators of Y1 to Y3 and Domain and scientific subject leaders met regularly to discuss proposed changes. Across all domains and Y1 to Y3, lecture hours decreased from $57 \%$ to $53 \%$ of teaching time, while other learning activities increased from $43 \%$ to $47 \%$ of teaching time.

Across $\mathrm{Y} 1$ to $\mathrm{Y} 3$, the basic sciences, including anatomy, biochemistry, cell biology, physiology, research and statistics, were cut by 74 hours (Table 2). In Y1 and Y2, these reductions were accomplished largely through reducing repetition between semesters and subject areas, eliminating non-core content, and subsequently amalgamating lectures. In Y3, most basic science laboratory practical sessions were reduced from three to two hours, through deleting non-core material and eliminating content repetitious with Y2.

Pathology, immunology and microbiology were cut by 37 hours. Clinical practice, including other clinical sciences, communication and clinical skills, pharmacology and radiology, was cut by 64 hours. As with the basic sciences, reductions were achieved by eliminating repetitive and non-core content. 
The professionalism and leadership domain was cut by 29 hours. However, some of the content cut from lectures was incorporated into case-based learning sessions, allowing greater small-group discussion of issues in context instead of didactic delivery. In contrast, the health and society domain and case-based learning sessions had no change in teaching hours. 


\section{Tables}

Table 1. Teaching hours per semester and per year before (2014) and after (2015) implementation of teaching-hour reductions.

\begin{tabular}{|l|r|r|r|r|r|r|r|r|r|}
\hline & \multicolumn{4}{|c|}{ Lectures } & \multicolumn{2}{c|}{ Other learning activities } & \multicolumn{3}{c|}{ Total } \\
\hline Unit or Year & $\begin{array}{c}\text { Before } \\
\text { reductions }\end{array}$ & $\begin{array}{c}\text { After } \\
\text { reductions }\end{array}$ & Change & $\begin{array}{c}\text { Before } \\
\text { reductions }\end{array}$ & $\begin{array}{c}\text { After } \\
\text { reductions }\end{array}$ & Change & $\begin{array}{c}\text { Before } \\
\text { reductions }\end{array}$ & $\begin{array}{c}\text { After } \\
\text { reductions }\end{array}$ & Change \\
\hline Y1S1 & 185 & 136 & $-27 \%$ & 110 & 113 & $+3 \%$ & 295 & 249 & $-16 \%$ \\
\hline Y1S2 & 138 & 106 & $-23 \%$ & 132 & 121 & $-8 \%$ & 270 & 227 & $-16 \%$ \\
\hline Year 1 & $\mathbf{3 2 2}$ & $\mathbf{2 4 2}$ & $\mathbf{- 2 5 \%}$ & $\mathbf{2 4 3}$ & $\mathbf{2 3 4}$ & $\mathbf{- 3 \%}$ & $\mathbf{5 6 5}$ & $\mathbf{4 7 6}$ & $\mathbf{- 1 6 \%}$ \\
\hline Y2S1 & 165 & 130 & $-21 \%$ & 113 & 113 & $0 \%$ & 278 & 243 & $-13 \%$ \\
\hline Y2S2 & 135 & 111 & $-18 \%$ & 149 & 146 & $-2 \%$ & 284 & 256 & $-10 \%$ \\
\hline Year 2 & $\mathbf{3 0 0}$ & $\mathbf{2 4 0}$ & $\mathbf{- 2 0 \%}$ & $\mathbf{2 6 2}$ & $\mathbf{2 5 9}$ & $\mathbf{- 1 \%}$ & $\mathbf{5 6 2}$ & $\mathbf{4 9 9}$ & $\mathbf{- 1 1 \%}$ \\
\hline Y3S1 & 79 & 69 & $-13 \%$ & 86 & 62 & $-27 \%$ & 165 & 131 & $-21 \%$ \\
\hline Y3S2 & 110 & 108 & $-2 \%$ & 30 & 21 & $-32 \%$ & 141 & 128 & $-9 \%$ \\
\hline Year 3 & $\mathbf{1 8 9}$ & $\mathbf{1 7 6}$ & $\mathbf{- 7 \%}$ & $\mathbf{1 1 6}$ & $\mathbf{8 3}$ & $\mathbf{- 2 9 \%}$ & $\mathbf{3 0 5}$ & $\mathbf{2 5 9}$ & $\mathbf{- 1 5 \%}$ \\
\hline Year 1-3 & $\mathbf{8 1 1}$ & $\mathbf{6 5 8}$ & $\mathbf{- 1 9 \%}$ & $\mathbf{6 2 0}$ & $\mathbf{5 7 5}$ & $\mathbf{- 7 \%}$ & $\mathbf{1 4 3 1}$ & $\mathbf{1 2 3 3}$ & $\mathbf{- 1 4 \%}$ \\
\hline
\end{tabular}

In Y3, teaching hours were only determined for the two teaching days per week that students were not engaged in workplace learning (clinical rotations). Totals may differ due to rounding to nearest whole number. 
Table 2. Teaching hours in curriculum areas across Years 1-3 before (2014) and after (2015) implementation of teaching-hour reductions.

\begin{tabular}{|l|r|r|r|r|r|}
\hline \multirow{2}{*}{ Curriculum area } & \multicolumn{2}{|c|}{ Before reductions } & \multicolumn{2}{c|}{ After reductions } & \multirow{2}{*}{ Change } \\
\cline { 2 - 5 } & Hours & Percentage & Hours & Percentage & \\
\hline Basic sciences & 473 & 33.1 & 399 & 32.4 & $-16 \%$ \\
\hline Pathology, immunology and microbiology & 276 & 19.3 & 239 & 19.4 & $-13 \%$ \\
\hline Clinical practice & 379 & 26.5 & 315 & 25.6 & $-17 \%$ \\
\hline Professionalism and leadership & 74 & 5.1 & 45 & 3.6 & $-39 \%$ \\
\hline Health and society & 99 & 6.9 & 99 & 8.0 & $0 \%$ \\
\hline Case-based learning & 95 & 6.6 & 95 & 7.7 & $0 \%$ \\
\hline Miscellaneous & 37 & 2.6 & 42 & 3.4 & $+16 \%$ \\
\hline Total & $\mathbf{1 4 3 1}$ & $\mathbf{1 0 0 . 0}$ & $\mathbf{1 2 3 3}$ & $\mathbf{1 0 0 . 0}$ & $\mathbf{- 1 4 \%}$ \\
\hline
\end{tabular}

Miscellaneous sessions included formative assessments, feedback on assessment, and informational introductions to components of the course. 
Table 3. The percentages (and numbers) of students not completing the academic year or failing the academic year and scores of those completing the year were not affected by teaching-hour reductions.

\begin{tabular}{|c|c|c|c|c|c|}
\hline & Year of the course & $\begin{array}{l}\text { Before reductions } \\
(2013 \text { and } 2014 \text { pooled })\end{array}$ & $\begin{array}{l}\text { After reductions } \\
\text { (2015 and } 2016 \text { pooled) }\end{array}$ & Test & $P$-value \\
\hline \multirow{4}{*}{$\begin{array}{l}\text { Did not complete the } \\
\text { academic year }\end{array}$} & Year 1 & $2.1 \%(5$ of 236$)$ & $2.1 \%$ (5 of 243$)$ & Fisher, & 1.00 \\
\hline & Year 2 & $1.8 \%$ (4 of 222$)$ & $3.8 \%$ (9 of 235$)$ & $\chi^{2}=1.699$ & 0.19 \\
\hline & Year 3 & $1.4 \%(3$ of 216$)$ & $2.5 \%(6$ of 237$)$ & Fisher & 0.51 \\
\hline & Years 1-3 pooled & $1.8 \%(12$ of 674$)$ & $2.8 \%(20$ of 715$)$ & $\chi^{2}=1.594$ & 0.21 \\
\hline \multirow{4}{*}{$\begin{array}{l}\text { Completed but failed the } \\
\text { academic year }\end{array}$} & Year 1 & $4.7 \%(11$ of 236$)$ & $4.5 \%(11$ of 243$)$ & $\chi^{2}=0.005$ & 0.94 \\
\hline & Year 2 & $4.5 \%(10$ of 222$)$ & $6.0 \%(14$ of 235$)$ & $\chi^{2}=0.484$ & 0.49 \\
\hline & Year 3 & $2.3 \%$ (5 of 216$)$ & $1.3 \%$ (3 of 237) & Fisher & 0.49 \\
\hline & Years 1-3 pooled & $3.9 \%(26$ of 674$)$ & $3.9 \%(28$ of 715$)$ & $\chi^{2}=0.003$ & 0.96 \\
\hline \multirow{3}{*}{$\begin{array}{l}\text { Percentage scores of } \\
\text { those who completed the } \\
\text { year (including failed) }\end{array}$} & Year 1 & $66.4(7.6)$ & $66.8(9.1)$ & t-test & 0.57 \\
\hline & Year 2 & $64.8(7.1)$ & $63.3(7.7)$ & t-test & 0.029 , n.s. \\
\hline & Year 3 & $66.7(7.8)$ & $68.4(8.2)$ & t-test & 0.027, n.s. \\
\hline
\end{tabular}

When one or more expected counts were less than five, Fisher's Exact test (2-sided) was used instead of the Chi-Square test. Scores are mean (standard deviation); the pass mark is 50. n.s., not significant at $P=0.017$. 
Table 4. Student opinions of MBBS units before and after teaching-hour reductions, collected via selected-response items of eVALUate

\begin{tabular}{|c|c|c|c|c|c|c|}
\hline \multirow[t]{2}{*}{ Item } & \multirow[t]{2}{*}{$N$} & \multicolumn{3}{|c|}{ Average Likert scale score } & \multicolumn{2}{|c|}{$\begin{array}{l}\text { Percentage agreeing } \\
\quad(\text { SA or A) }\end{array}$} \\
\hline & & $\begin{array}{c}\text { Before } \\
\text { reductions }\end{array}$ & $\begin{array}{c}\text { After } \\
\text { reductions }\end{array}$ & $P$-value & $\begin{array}{c}\text { Before } \\
\text { reductions }\end{array}$ & $\begin{array}{c}\text { After } \\
\text { reductions }\end{array}$ \\
\hline All items pooled & 909 & $3.05(0.41)$ & $3.12(0.41)$ & 0.014 & & \\
\hline Q1. The learning outcomes in this unit are clearly identified. & 1084 & $3.15(0.67)$ & $3.23(0.62)$ & 0.06 & $88 \%$ & $91 \%$ \\
\hline $\begin{array}{l}\text { Q2. The learning experiences in this unit help me to achieve the } \\
\text { learning outcomes. }\end{array}$ & 1081 & $3.13(0.55)$ & $3.14(0.54)$ & 0.86 & $91 \%$ & $92 \%$ \\
\hline $\begin{array}{l}\text { Q3. The learning resources in this unit help me to achieve the } \\
\text { learning outcomes. }\end{array}$ & 1079 & $3.12(0.56)$ & $3.13(0.56)$ & 0.81 & $92 \%$ & $89 \%$ \\
\hline $\begin{array}{l}\text { Q4. The assessment tasks in this unit evaluate my achievement of } \\
\text { the learning outcomes. }\end{array}$ & 1045 & $2.76(0.74)$ & $2.91(0.66)$ & $0.003 *$ & $69 \%$ & $74 \%$ \\
\hline $\begin{array}{l}\text { Q5. Feedback on my work in this unit helps me to achieve the } \\
\text { learning outcomes. }\end{array}$ & 1013 & $2.75(0.78)$ & $2.83(0.76)$ & 0.13 & $64 \%$ & $67 \%$ \\
\hline $\begin{array}{l}\text { Q6. The workload in this unit is appropriate to the achievement of } \\
\text { the learning outcomes. }\end{array}$ & 1063 & $2.80(0.70)$ & $3.04(0.56)$ & $<0.001 *$ & $73 \%$ & $85 \%$ \\
\hline $\begin{array}{l}\text { Q7. The quality of teaching in this unit helps me to achieve the } \\
\text { learning outcomes. }\end{array}$ & 1085 & $3.10(0.60)$ & $3.14(0.62)$ & 0.25 & $88 \%$ & $89 \%$ \\
\hline Q8. I am motivated to achieve the learning outcomes in this unit. & 1071 & $3.17(0.64)$ & $3.18(0.65)$ & 0.78 & $89 \%$ & $87 \%$ \\
\hline Q9. I make best use of the learning experiences in this unit. & 1076 & $3.10(0.61)$ & $3.14(0.59)$ & 0.37 & $86 \%$ & $88 \%$ \\
\hline Q10. I think about how I can learn more effectively in this unit. & 1066 & $3.20(0.62)$ & $3.29(0.59)$ & 0.025 & $88 \%$ & $91 \%$ \\
\hline Q11. Overall, I am satisfied with this unit. & 1087 & $3.07(0.57)$ & $3.11(0.55)$ & 0.22 & $90 \%$ & $92 \%$ \\
\hline
\end{tabular}

' $N$ ' is the number of responses, excluding 'unable to judge' and missing responses. Likert scale data before and after reductions are mean

(standard deviation) with $1=$ SD to $4=$ SA. $P$ values are from t-tests for all 11 items pooled, or from Mann-Whitney U tests for individual items. 
* Statistically significant at $P<0.004$ (0.05/12). Items are from version 3 of the unit eVALUate survey, in Oliver B, Tucker B, Gupta R, Yeo S. 2008. eVALUate: an evaluation instrument for measuring students' perceptions of their engagement and learning outcomes. Assessment \&

Evaluation in Higher Education. 33(6):619-630. Reprinted by permission of the publisher (Taylor \& Francis Ltd, http://www.tandfonline.com). 
Figure 1

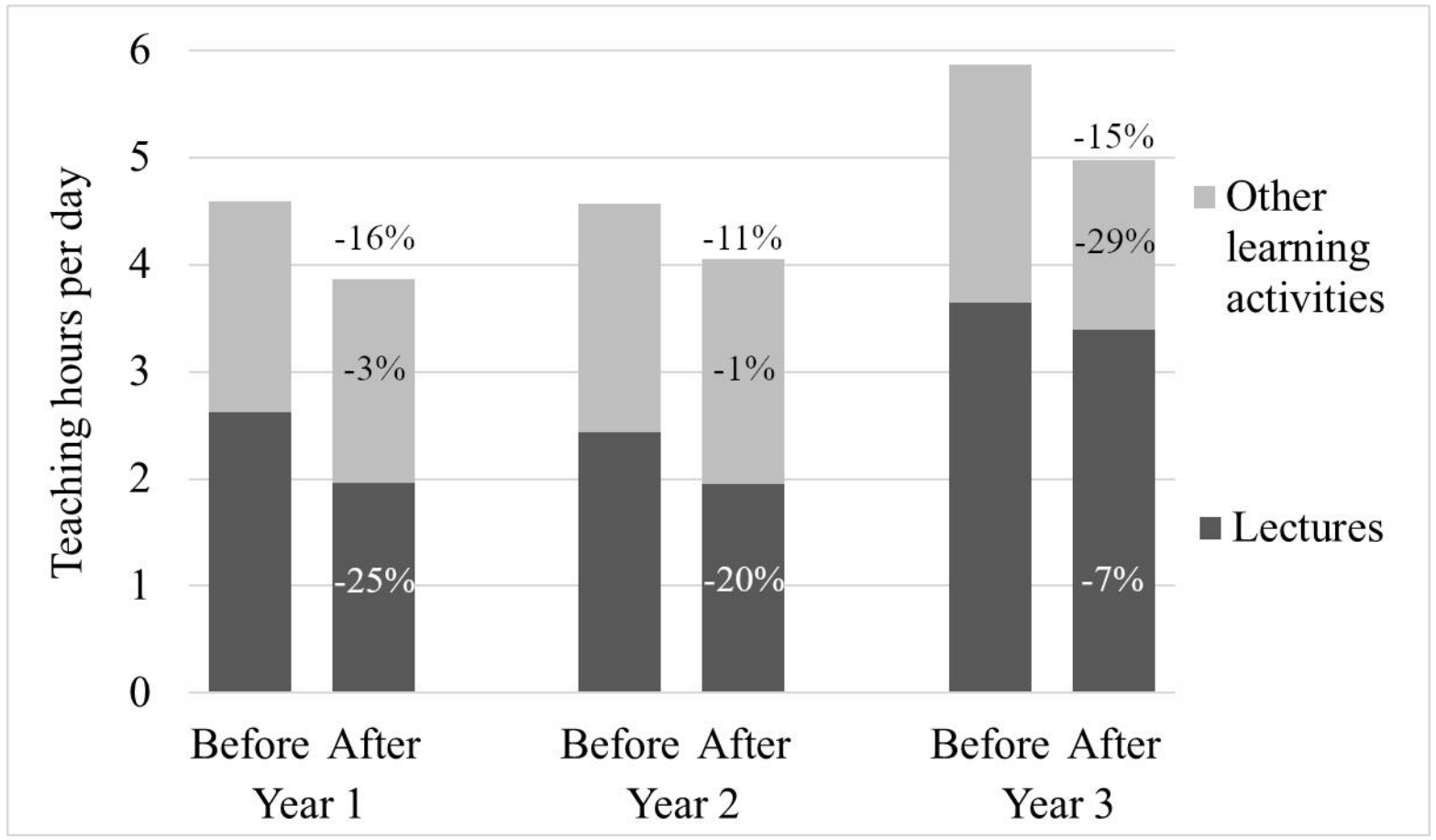

Figure 1. Average teaching hours per day in Years 1,2 and 3 of the MBBS course before and after implementation of teaching-hour reductions. 